\title{
PUBLIC RANGE LANDS-A NEW POLICY NEEDED
}

\author{
ROMANZO ADAMS \\ University of Nevada
}

I

The United States owns more than four hundred million acres of public land, exclusive of the land in Alaska and other outlying possessions, and by virtue of this ownership the nation is one of the world's greatest landlords. Nearly three-fifths of the land in the whole Intermountain Region is still in public ownership. These public lands constitute an area about four-fifths as large as that part of the United States which lies east of the Mississippi River. Some of this land possesses valuable forest and mineral resources. A limited amount will be made available for farming through the development of irrigation enterprises and dry-farming methods, but the greater part of this vast area is more valuable for grazing than for cultivation or other purposes. While these grazing lands have small value per acre, the vastness of their extent gives them sufficient importance to make their management one of the vital economic and social problems of the Intermountain West. Up to the present time the national government has been remiss in relation to its duties as a landlord.

The fundamental idea of nineteenth-century national policy in relation to the public lands was that they should be disposed of to private holders as rapidly as required by the growing population, and in such a way as to contribute to the general welfare and particularly to economic and political stability. The more important features of this policy were designed to give men of little wealth an opportunity to own their own homes and farms. Some of the land was sold at a very low price, but much more was given away to homesteaders and in encouragement of education and transportation. In nearly all cases the land laws contained provisions favoring the landless man and the actual settler. The aim was to give the worker a sufficient amount of land to enable him to apply his own labor effectively and to maintain his family according to 
a reasonable standard. The laws discriminated against the land speculator and the man who wished to acquire great holdings. It was recognized that a wide distribution of land ownership was essential to the development of sound social conditions.

From this standpoint public ownership was a temporary incident preceding the settlement of the country and the utilization of the land. There was need for a policy of land disposal by sale or gift, but not for a policy of land management. Under the practical conditions presented by the great Mississippi Valley this policy worked pretty well. The land was well watered, not mountainous, and nearly all of it passed into farms of a desirable size at a comparatively early date. But the land now under consideration is, for the most part, unfit for cultivation, and the general interest will be best served by a policy of permanent public ownership with an appropriate system of management under government regulations.

Two general facts may be cited as evidence in support of the proposition that the.policy of disposal by gift or sale is not working well in relation to the grazing lands of the Intermountain West. In the first place, the land of the character under consideration is not passing into private ownership in significant quantities. For example, seven-eighths of the total land area of Nevada is still included in the public domain. The other eighth is made up chiefly of land given away by the national government for the encouragement of education and railroad building. The amount of land disposed of in other ways is extremely small, although Nevada has been a state for more than a half-century. Only about 4 per cent of the area of this state was reported as in farms in I9ro, and only I per cent was improved. A homestead and sales policy that does not result in the disposition of the land is, in so far, a failure. In the second place, the social results have not been such as were contemplated by the law. Instead of numerous small farms cultivated by their owners, we see great land holdings owned largely by corporations and managed in such a way as to create conditions unfavorable to the welfare of the laborers and the public. A policy originally conceived in the interest of social welfare now works to an opposite result. Moreover, it is highly probable that any 
policy designed to increase the area of privately owned range land would only intensify the evil.

Some progress has been made in the development of a publicland policy adapted to the Intermountain States. Among the more important features of this new policy are the provisions for irrigating arid lands, for the regulation and management of forest reserves, for the control of coal and oil lands, and for the regulation and control of water-power sites. There remains, however, the problem of developing a system of management for the great area that is more valuable for range pasturage than for other purposes. In relation to these lands the national government still pursues the policy of neglect, permitting stockmen to utilize the pasturage, but not regulating such use.

In the absence of a system of legal regulation there has grown up a body of customs among the stockmen which may be called the "law of the range." This law of the range is based on an understanding among the stockmen whereby each is supposed to recognize the customary rights of the others. In general, the growth of respect for these range customs has served to lessen, but not to stop, private wars among the stockmen, and has contributed to the less destructive use of the pastures. The outcome, however, is a system which tends to destroy the value of the range.

The main contention of this paper is that the national government should retain the ownership of those public lands which are more valuable for pasturage than for cultivation, and, in relation to such lands, should adopt a policy of regulation and control, and that this policy should be determined primarily with reference to the creation and development of sound social conditions.

The eight states of the Intermountain Region, comprising Montana, Wyoming, Colorado, New Mexico, Idaho, Utah, Nevada, and Arizona, possess certain characteristics in common. With small exception the surface of the whole region is an elevated plateau with numerous lofty mountain ranges. There is a marked variety of temperature and precipitation in the different localities of each state due to differences of altitude. The precipitation nearly everywhere is too small to permit of ordinary agriculture, but farming by irrigation and range stock grazing are prominent 
industries in every state, and in most of them important progress in agriculture by dry-farming methods has been made in favorable localities.

The population of all these states is sparse. Their combined population (rgro) is less than that of the state of Indiana, while their combined area exceeds that of all the states east of the Mississippi River. This paucity of population is explained in some measure by the fact that much of the region is still in the pioneer stage of development. Doubtless there will be a considerable increase in population as the resources of the region are more fully utilized, but the outstanding fact is that, on account of the deficiency of water, the region is not adapted to the maintenance of a large agricultural population.

But too much emphasis must not be put on the common characteristics. In a region extending from Canada to Mexico and from the Sierras to the Great Plains there cannot fail to be important differences in climatic conditions, and these are sure to affect the economic and social circumstances of the various states. In general, precipitation is greater in the higher altitudes, but it is modified by other factors. ${ }^{x}$ A moderate difference in rainfall may result in a radical difference in economic and social conditions. In a region with twelve inches of rainfall dry-farming is impracticable and there is little water for irrigation. ${ }^{2}$ Consequently there is but

\footnotetext{
I Average annual precipitation of each of the Intermountain States for the years I899-I9r4:

Nevada......... 9.30 inches Wyoming....... 44.25 inches

Utah............ I3.02

Arizona........... I3.34

New Mexico......... I 3.94

Montana............ I5.98

Colorado........... I6.80

Idaho.............. I 7.60
}

Part of the data on which these averages are based are for the mountain altitudes, where the snowfall may be two or three times as great as in the adjacent valleys. If measurements were taken only for the altitudes in which farming is practicable, the averages would be lower. Furthermore, the Weather Bureau stations are often located on farms, and, since farms are more mumerous in the sections of greater precipitation, the data tend to be representative of the less arid parts of the respective states.

2 These figures are not to be taken too precisely. The amount of rainfall necessary to make dry-farming successful depends on the character of the soil, the humidity of the air, the seasonal distribution of the rain, and the character of the cultivation. The significant fact is that at a certain point a small increase in precipitation works results vastly disproportionate to the amount of water. Sixteen inches of precipitation may support five times as much agriculture as ten inches. 
a scanty population, and the chief occupation is cattle and sheep raising. Sixteen inches of rainfall results in a much more abundant supply of water for irrigation, and dry-farming may be feasible where irrigation is not practicable. The population, therefore, is much more dense, the land is owned in smaller holdings, and the labor conditions and general social conditions are correspondingly better.

A few examples may serve to make this point clearer. As one proceeds eastward through Nevada, Utah, and Colorado, there is an increase of precipitation, and chiefly as a result of this increase Colorado has a much larger acreage of dry farms and of irrigated land, and the pastures of that state support a larger amount of live stock. ${ }^{\mathrm{x}}$

Furthermore, there are some marked variations in the system of land ownership and in social conditions which are the results of special historic circumstances. For example, the land system of New Mexico had its origin in old Spanish and Mexican grants. Consequently much of the grazing land is owned in very large, compact areas, and the irrigated land is largely in the hands of people of Mexican descent whose holdings are unusually small.

Utah also presents some features of unique interest. It was the first of the Intermountain States to be settled by an Englishspeaking people, and these people came mainly from religious motives. It was the policy of the Mormon church to encourage the subdivision of the cultivable land into small farms, and this has contributed greatly to the economic and social stability of that state. In marked contrast to Utah stands Nevada, where most of the irrigated land is owned by a small number of great land and live-stock corporations and where there are very few farms and

$\therefore$ The following table shows conditions:

\begin{tabular}{|c|c|c|c|}
\hline & Nevada & Utah & Colorado \\
\hline 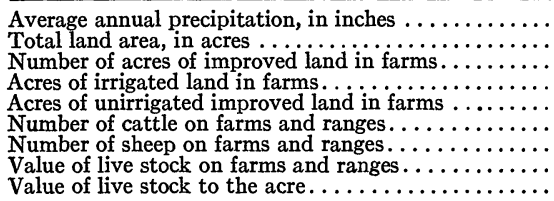 & $\begin{array}{l}9 \cdot 30 \\
70,285,440 \\
752, \mathrm{rr} 7 \\
701,833 \\
50,284 \\
449,68 \mathrm{r} \\
\mathrm{r}, \mathrm{r} 54,795 \\
\$ 19,07 \mathrm{r}, 809 \\
\$ 0.26\end{array}$ & $\begin{array}{l}13.02 \\
52,597,760 \\
1,368,2 \mathrm{rr} \\
999,410 \\
368,801 \\
412,334 \\
1,827,180 \\
\$ 28,330,215 \\
\$ 0.53\end{array}$ & $\begin{array}{l}16.80 \\
66,341,120 \\
4,302, \text { ror } \\
2,792,032 \\
r, 5 \text { ro,o69 } \\
r, 127,737 \\
r, 426,214 \\
\$ 68,840,485 \\
\$ 1.03\end{array}$ \\
\hline
\end{tabular}


farm homes. Nevada was first settled by gold and silver miners, if, indeed, men who lead so migratory a life could be called settlers. The aleatory character of the early mining industry has influenced the whole economic and social development of the state. Other examples could be cited, but these are sufficient to show that uniform conditions do not prevail over the whole Intermountain Region. There is need for a detailed study of each section of the region under consideration, so that there may be a public-land policy sufficiently elastic to permit of local adaptations. Uniformity of procedure is not desirable where conditions are not uniform.

In view of the diversity of conditions it will simplify the treatment to confine this discussion to one state, Nevada, with the general understanding that the main conclusions apply in considerable measure to those parts of the other states in which the use of public range lands is dominated by a comparatively small number of big stockmen. ${ }^{x}$

It may be well at this point to state the thesis of this paper somewhat more precisely. The national government should retain the ownership of those public lands which are situated in Nevada and which are more valuable for range pasturage than for agriculture or other purpose, and should regulate and control the use of such lands in such a way as to conserve and utilize their value more fully and with primary reference to the creation and maintenance of conditions favorable to social welfare.

The entire area of Nevada lies in the arid or semi-arid region east of the Sierras. This region is, in the main, a plateau of from three to six thousand feet elevation intersected by a large number of parallel ranges of mountains whose trend is north and south. The precipitation is confined chiefly to the winter months of the year, the growing season being almost rainless. The average annual precipitation of the valleys of the northern part of the state is, in general, too small to permit of successful farming

I It is not held that Nevada is the most typical state of this group. On the contrary, it is in Nevada that certain tendencies have reached their most extreme development. This extreme development makes it possible to trace the cause-and-effect relation with the greater certainty, and is, therefore, advantageous to the investigator. 
without irrigation, although there are a few small areas where dryfarming may be practicable. The snowfall in the higher mountains is sufficient to give rise to perennial streams of sufficient size to irrigate a comparatively small part of the valley lands. In the southern part of the state the precipitation is nearly negligible in the valleys, and the mountain snows give rise to only a few small streams, most of which are dry in the late season.

There are four rivers of considerable size in the state. Three of these, the Truckee, the Carson, and the Walker, draw their waters from the high Sierras of California and contribute them to the irrigation of farm lands in Nevada. The Humboldt has its origin in the higher mountain ranges of northeastern Nevada and flows in a general westerly direction three-quarters of the distance across the state. These four rivers supply more than four-fifths of all water used for irrigation. Agriculture, therefore, is confined mainly to the districts watered by these rivers.

The total land area of the state is $70,285,440$ acres. About seven-eighths of this is still in public ownership, there being 5,557 ,oro acres in forest reserves ( $\mathrm{I}_{9} \mathrm{I}_{5}$ ) and $55,4 \mathrm{I} 7,746$ acres unappropriated and unreserved. Of the land not in public ownership, 2,7 I4,757 acres were reported as in farms in I9I0, the remainder being chiefly railroad-grant lands, most of which are still owned by the railway companies and are valuable only for range pasturage. Most of the farm land of Nevada is land that was granted to the state for school purposes. A relatively small acreage represents the sale of railroad-grant lands, and a little of the public domain has been purchased or homesteaded.

The 2,7 14,757 acres reported as in farms constitute about 4 per cent of the area of the state, and of this amount only 70r,833 acres, or about I per cent of the entire land area, were under irrigation in I9Io. A man of wide knowledge of agricultural conditions in Nevada has estimated that Nevada has sufficient water, if it were fully conserved and economically applied, to irrigate two million acres, or about 3 per cent of its area. Because of the high cost of construction of the needful dams and ditches, because of some legal difficulties involved in the storage of winter waters, and because of the more or less wasteful habits of water-users, progress in 
extending the irrigated area is not rapid, and it appears probable that after about a million acres shall have been placed under irrigation the rate of increase will be still slower. The important facts are that about 97 per cent of the area of the state has little or no value for agriculture, now or prospectively, except for grazing purposes, and that the national government is still the owner of nearly all of this grazing land.

The method of utilizing the range pastures depends largely on climatic conditions-chiefly on the amount of precipitation in the form of snow. In the northern half of the state, particularly in the more elevated parts, the snowfall is sufficient to provide for summer pasturage of considerable value and for drinking-water. This very abundance of snow makes the northern ranges undesirable for winter use. Farther south there is less snow-so little that sheep can pick their living in winter in the lower altitudes. The light snowfall, however, means little pasturage and no water for summer use. It is the custom, therefore, for the sheepmen to drive their herds to the north in summer, advancing into the higher mountains in the warmer season, and to return to the more southern lands in winter. Thirty years ago cattle commonly lived on the range in winter, but at present winter feeding is the more common procedure, while the cattle graze on the mountain ranges in summer. Sheep are always herded in bands, while cattle are permitted to wander at will during the summer, except that they are driven up into the higher mountains where the better summer pastures are found. Relative to need, the winter ranges are the more abundant. The limit to live-stock production is therefore set by the available summer pastures.

The privately owned farm and range lands of Nevada have two sorts of utility: (I) utility in production of farm crops, and (2) utility in the control of adjacent public range lands. More than nine-tenths of the irrigated land (r9ro) is devoted to pasturage and hay production. About one-twentieth is given over to the growing of grain, which is used chiefly as feed for live stock. The unirrigated privately owned land, comprising about three-fourths of all farm land, consists of range pasture land selected in such a way as to control nearly all of the water available for drinking 
purposes. Through the ownership of the land with water, the use of the public range lands is, in large measure, controlled.

The control of the use of the public range lands through the ownership of sources of drinking-water is more or less common in the other states, but it is unusually important in Nevada. There is less watered land here than in the other states, and hence a given source of water controls a wider area. Moreover, nearly all of Nevada's school lands were granted under special conditions, all the land being selectable. The laws of the state were such that a stockman could buy an amount of land limited only by his supply of money, and he could select just the forty-acre tracts on which water was found. ${ }^{x}$ This could not be done elsewhere, for in all the other states the school lands consisted of certain numbered sections according to the United States surveys. The buyer of such school lands could not select the areas with water, and so their ownership did not confer control over adjacent districts. It may be added that the provisions of the national laws regarding homesteads and land sales were designed to prevent the acquisition of large holdings; and consequently, where the school lands could not be used for such purpose, it was rather difficult for a man to make use of the Nevada system of range control through water monopoly.

The method through which this control was secured may be illustrated by a typical case: In a certain place there was a small stream formed by the union of two branches. These branches bounded two sides of a triangular area about 30 miles on each side. Forty-acre tracts following up the main stream and up each branch to its source were purchased; also all irrigable lands, which were chiefly along the lower course of the stream. The purchase of a number of additional forty-acre tracts here and there where water was found was sufficient to give the owner practical control over all the pasturage in the adjacent mountains, for competitors cannot use the pastures unless they can get drinking-water. The

r A man could purchase 640 acres directly, and then, using the names of his relatives, friends, and employees, he could get as much more as he needed. The land sold at $\$$ r. 25 per acre, but only 25 cents had to be paid at the time of purchase, and long time was given for the balance. Consequently a man with $\$$ ro,000 could buy 40,000 acres, and through this he could control the use of, perhaps, a million acres of public land. 
control of the area between the branches of the stream is the more perfect because the privately owned land practically fences this part of the public domain. In this way an owner of 40,000 acres may secure the control of the pasturage of public land of much larger area.

It should not be inferred that this control is perfect. In some localities a competitor may, by some digging, find water the presence of which is unknown to the landowner. In the earlier summer there is water in many places regarded as dry because they are dry in the late summer. Consequently there is more or less competition between the established stockman supposed to be in control and the interloping small competitor. This competition works badly in several ways. Two or more bands of sheep may feed over the same range, the first taking all the plant life that should be taken and the second and third tramping in and pulling out the roots of forage plants and preventing natural reseeding. In this way the value of the range pastures has been greatly diminished. Range conservation cannot be practiced where there is competition of this kind, for if one man should try to use right methods he would merely resign the use of the land to his more ruthless competitors. It should be perfectly clear that bad range methods and range deterioration are the natural and inevitable results of the present system where there is competition, actual or potential. ${ }^{\mathrm{r}}$

A further bad effect of this competition is found in the controversies and private wars among the stockmen. It is not necessary here to relate the history of these conflicts, except to say that, in the absence of appropriate legal remedies, resort to violence has been frequent and that there is much to support the view that in the range live-stock industry of the early days success was to the most ruthless. The amount of violence is decreasing as competition is giving way to control through water monopoly and through an understanding among the big landowners.

It is hard to say just how far this control has been carried. The census of rgro shows that more than 82 per cent of all farm

I The benefits of legal regulation are evident in the forest reserves where, as a result of a controlled use, the pasturage is now far more abundant than it was before this control was established. 
land in the state was in 344 so-called farms. These farms or ranges varied in size from $\mathrm{I}, 000$ to $\mathrm{I} 75,000$ acres, and the average size was 6,530 acres. (It should be remembered that these figures represent the land privately owned, and that the owners utilize the pastures of public lands of ten or twenty times greater area.) There are not, however, as many owners as there are farms reported, since many of the large owners have several ranges in widely separated parts of the state. Most of the land is in corporate ownership. Sometimes the corporation is essentially a family corporation and sometimes it represents a consolidation of the interests of several families. Furthermore, there are very close relations between the stock-raising interests and the local banks, and it is not improbable that the banks often serve to promote unity of action and to prevent predatory competition.

Taking into consideration all of these facts, and the further fact that a considerable number of the 344 farms previously mentioned are not greatly in excess of a thousand acres in size, it appears probable that less than a hundred of the larger individual and corporate owners hold approximately three-fourths of the privately owned land in the state and control a still larger proportion of the public range land.

In no other state is this concentration of ownership carried so far. In no other state are there so few farmers. In no other state is the average size of farms so large. In no other state is the average number of cattle or sheep so great for the farms reporting. In no other state are there so many migratory farm employees in proportion to the number of farms. ${ }^{\mathrm{I}}$

I shall point out later how this big ownership is a source of some very serious social evils, but under existing circumstances it has some advantages, not only for the owners, but for the public. The

I Utah has 19,709 irrigated farms with an average of 50 acres of irrigated land each; Idaho, 16,439 irrigated farms of 87 acres of irrigated land each; Nevada, 2,406 irrigated farms of $29 \mathrm{I}$ acres of irrigated land each. The number of sheep to the farm reporting is, for Utah, 769; for Idaho, I,026; for Nevada, 3,677. The number of cattle to the farm reporting is as follows: Utah, 2I; Idaho, I6; Nevada, 210. The number of employed laborers to roo farmers is as follows: Utah, 44; Idaho, 47; Nevada, I56. Had the census been taken a month or two later, during the haymaking season, the number of employed men in Nevada would have been very much larger. 
larger the amount of land owned by a single corporation and the more fully it enters into understandings with the owners of other land in adjacent districts, the more perfect is the control of water sources and the less the danger from competition. The less the competition, the less violence arises out of stockmen's conflicts. The less the competition, the less destructively is the range used. Such control, if complete, would enable the stockmen to make use of conservation methods on the public land. Indeed, perfect control would make the public land, to all intents and purposes, the private property of the corporations that own the adjacent watered lands. It is probable that present tendencies, if continued, would at no distant date result in such a control, and this result would be desirable as against a continuation of the present conditions. A better arrangement, however, would be regulation and control by the national government. The chief ground for objection to a system of large ownership is that it creates bad labor conditions and prevents the multiplication of small farms and farm homes.

\section{LABOR CONDITIONS}

In a region of diversified and moderately intensive agriculture the demand for labor is pretty steady throughout most of the year. Where farms are small, the labor is performed mainly by the farmers and the members of their families. The employed farm laborer usually gets pretty steady employment. If married he may have his home on the farm on which he works, and if single he ordinarily lives in the home of his employer and is treated in many ways as a member of the family. Frequently the hired man is a neighbor's son, and, if so, he is a permanent member of the community, entering into the general social life of the neighborhood and living in his father's home when temporarily unemployed. Under these conditions there is no special problem of farm labor in the sense in which such a problem exists in some parts of the Intermountain and Pacific states. The special problems of farm labor in the West are explained by reference to two facts: (I) agriculture lacks diversification, nearly all the land in many districts being devoted to the production of a single crop; (2) in those regions where the land is owned in large holdings, nearly all of the work is 
performed by hired laborers, the farmer and his family contributing but little to the total labor supply. Large-scale farming and stock raising call for large numbers of hired workers, and the seasonal demand due to the lack of diversification of crops makes the demand irregular. These conditions have called into existence a large body of migratory laborers, men who work in the hayfields, the wheatfields, and the orchards of several states, traveling about according to the season. These men may work a week or a month in one place, then travel a hundred or five hundred miles to the next job, and so on throughout the year. Sometimes they pay transportation expenses, but frequently they beat their way. In this way the West has developed a labor supply of maximum mobility. This extreme mobility of labor possesses an undoubted advantage, since it enables each district to specialize in the production of the commodity which is most profitable to the landowners; but these advantages come at too high a cost, since the system is bad for the workers. An industrial system cannot be justified on the ground that it produces great quantities of material wealth or that it makes some men rich. It must create conditions favorable to the welfare of the people who do the work.

These migratory farm workers are nearly always homeless, since a man with a family cannot move about freely and easily. ${ }^{\mathrm{I}}$ There are some boys and young men who may be considered as temporarily absent from home, but those who follow the life for any considerable time tend to lose all connection with their former homes, and they have no home in prospect. If they have relatives,

× The fact that Nevada has a large homeless population is made evident by data found in the United States Census for xgro. To each roo adult females there were 220 adult males, and the ratio is still more disproportionate if the Indians are not counted. The number of married women was equal to about one-third of the adult males. The number of children six to fourteen years of age was less than two-fifths as large as it should have been to approximate the usual ratio to adult males. Utah, with natural resources not greatly in excess of those of Nevada, had more than eight times as large a school population. On the basis of the census reports it appears that practically one-half of the men of Nevada were living outside of home environment. Most of these live a migratory life. The figures would have revealed even worse conditions had the census been taken a month or two later, when the ranks of the migratory workers were recruited by the haymakers. The responsibility for these conditions does not rest solely on the live-stock industry, since mining also contributes its quota of migratory men. 
they do not correspond with them. They do not stay long enough in any one place to get into normal human relations with the people of the community. Ordinarily they have no social contact with the employers or the members of the employers' families. They live apart, they are boarded in gangs, and each man carries his sleeping-blankets. It is only a slight exaggeration to say that these men are wholly outside of the institutionalized life of society. No home, no church, no fraternal organization, no club, no educational agencies, no means of beneficial recreation and amusement are for them. The open doors are the doors to vice. Since work is intermittent, they have frequent intervals of idleness, and since they have only themselves to support, they may have more money than they know how to spend wisely, and they never save. The old saying, "The Devil tempts all men except the idle and the idle tempt the Devil," is too true in their case, and the more true because they are, much of the time, supplied with money beyond their realized needs. Throughout the long course of human evolution men have lived under home conditions, surrounded by relatives and fellow-clansmen or neighbors and firmly established in the institutional life of society. When they are deprived of these essential human relationships they are, in a very important sense, dehumanized. It is as certain that men living under such circumstances will go to the bad as it is that an uprooted tree will die. Normal contact with society is as essential to one as normal contact with the earth is to the other. At the worst these men have no apparent aim in life beyond the satisfaction of immediate physical needs and the gratification of degraded appetites and desires. The great majority of all migratory farm workers are at some stage of deterioration, and when this deterioration reaches a certain point they are at first very inefficient workers and finally not workers at all-just tramps, vagabonds, drunkards, drug fiends, criminals, paupers, and insane. The statistics of Nevada's prison, jails, almshouses, and hospital for the insane bear testimony to the degrading influence of the migratory life. Ordinarily crime, pauperism, and insanity are found chiefly in the great cities, while the rural regions have few of such unfortunates; but Nevada, a state with no large city, has an overflowing population in her 
prison, her jails, her almshouses, and her hospital for the insane. Nevada has from two to six times as large a percentage of its population in prison, jails, almshouses, and hospital for the insane as have certain neighboring states where farms and farm homes are numerous and where migratory workers are few. ${ }^{\mathbf{I}}$ The amount of crime, pauperism, and insanity does not, of course, represent the full measure of the evils arising out of bad labor conditions. Out of the thousands of men whose lives are being undermined, only a few hundred are sent to penal and charitable institutions each year, but all share in the evils arising from the abnormal circumstances of their lives. Furthermore, the existence of so many homeless migratory workers is a menace to the welfare of the state. Let no society imagine that it can afford to be indifferent to the welfare of its workers, for they will, consciously or unconsciously, take their revenge.

The labor involved in the management of one of Nevada's great live-stock ranches may be divided into two classes according to the steadiness or irregularity of employment which they offer. The men who are in immediate charge of the cattle and sheep may secure pretty steady work. Haymakers and harvesters are employed in large numbers for a few weeks at a time. In neither

The following table shows conditions:

\begin{tabular}{|c|c|c|c|}
\hline & Nevada & Utah & Idaho \\
\hline 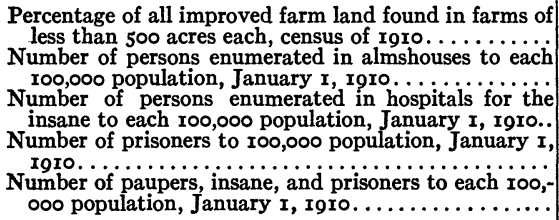 & $\begin{array}{r}19 \\
\text { r94 } \\
280 \\
353 \\
827\end{array}$ & $\begin{array}{r}72 \\
48 \\
91 \\
\text { ro6 } \\
245\end{array}$ & $\begin{array}{r}82 \\
29 \\
\text { Ir9 } \\
88 \\
236\end{array}$ \\
\hline
\end{tabular}

Several years ago someone wrote an article in which it was maintained that the monotony and lonesomeness of farm homes in the West was a leading cause of insanity, and that the farmers' wives in particular were the victims of this unfortunate situation. This statement has been repeated so often that many people believe it to be true, but the statistics all point the other way. There are very few insane persons in the institutions of those western states in which farm families are numerous, and the proportion of women is particularly small. The insane are recruited from the migratory workers. The isolation of a person who has a home on a remote farm is not so profound as is the isolation of a man with a home nowhere. 
case, however, is it feasible for the laborer to have a home, and, in practice, the work which might give rise to steady employment is performed largely by migratory workers. Stockmen find it diffcult to secure steady men even where steady employment is offered. Except for a few farm superintendents and managers, practically all workers on these great ranges are homeless and probably ninetenths are migratory. As a consequence the greater part of Nevada, even where there is water to irrigate the land, is deprived of a permanent population. The smallness of Nevada's population is due, not altogether to the paucity of its resources, but to the way in which these resources are used. This fact may be made more evident through a comparison of Nevada with Utah, a state of about equal natural agricultural resources, but with a better system of land ownership. ${ }^{x}$

In Utah the irrigated land is divided into a comparatively large number of small farms under a moderately intensive system of cultivation, while most of Nevada's irrigated land is in great ranches and in a comparatively low state of cultivation. Utah has (in 1910) 19,709 irrigated farms, Nevada only 2,406. Utah's irrigated farms average 50 acres of irrigated land each, those of Nevada 29I acres. Farms of less than 500 acres each include 72 per cent of the improved land in Utah and only r9 per cent of the improved land of Nevada. As a consequence Utah, with about equal natural resources, has a stable farm population of more than a hundred thousand people and a small population of migratory farm laborers, while Nevada has a stable farm population of about

I The average annual precipitation for Utah is 13.02 inches and for Nevada only 9.30 inches. As a consequence the run-off from melting snows is much greater for Utah, but this advantage is largely offset by two facts: (I) a very considerable part of the water of Utah's streams is not available for irrigation because the streams in the eastern part of the state lie in deep, narrow canyons where there is little available land; (2) much water runs to the sea unused. On the other hand, Nevada is able to utilize practically all the water falling within its own borders and it receives the waters of three considerable rivers which have their origin in the high Sierras of California. Furthermore, the area of Nevada is about one-third larger than that of Utah. All in all, the possibilities for agriculture are about equal for the two states, and the same is true as to range pastures. The actual amount of land irrigated in Nevada (Igro) is about 30 per cent less than Utah's irrigated area, the latter state having developed its resources more fully. 
ten thousand people and a very large population of migratory laborers. This difference in the size and ownership of farms and in the situation of the men who do the farm work accounts in large measure for many other differences between these two states of similar and approximately equal natural resources. Table I reveals some of these differences.

TABLE I

\begin{tabular}{|c|c|c|}
\hline & Nevada & Utah \\
\hline 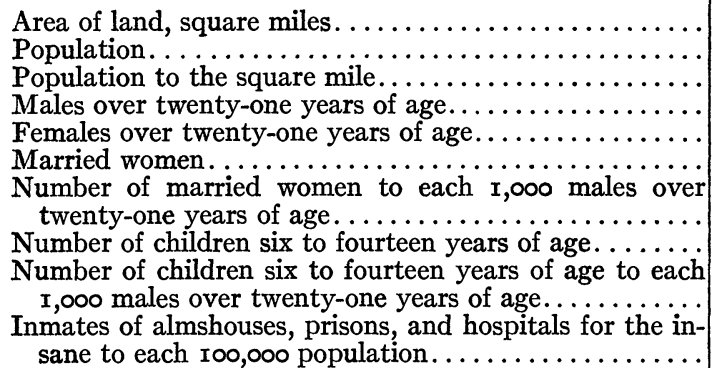 & $\begin{array}{l}109,821 \\
8 \mathrm{r}, 875 \\
0.7 \\
40,026 \\
18,140 \\
14,109 \\
35^{2} \\
9,412 \\
235\end{array}$ & $\begin{array}{r}82, \mathrm{I} 84 \\
373,35 \mathrm{I} \\
4 \cdot 5 \\
\mathrm{rO4,1} 5 \\
85,729 \\
66,255 \\
636 \\
76, \mathrm{I} 52 \\
73 \mathrm{I} \\
245\end{array}$ \\
\hline
\end{tabular}

From such data as I have been able to obtain I have estimated that the farms and ranges of Nevada support directly a homedwelling population of about ten thousand people, and of this number about eight thousand live on the farms, the other two thousand, chiefly the families of the larger landowners, living in cities and towns. If the land were subdivided and properly usedas similar land is used in Utah-it would support a farm population of a hundred thousand people, and this stable farm population would support numerous villages and towns. Anyone who is at all familiar with practical conditions will readily see that the securing of so large a stable population is a matter of vital importance to the state.

\section{II}

In the previous chapter certain facts relative to the land situation and labor conditions in Nevada were set forth. They may be summarized briefly as follows: 
I. About seven-eighths of the land of Nevada is still in the ownership of the national government and, in relation to most of this land, the government fails to perform its duty as landlord.

2. By far the greater part of the privately owned land, including most of the irrigated land, is in the hands of a few great corporations which, through this ownership, secure the control of the public pasture lands of the state.

3. Most of the irrigable land on these great ranches is in a comparatively low state of cultivation, since it is used almost exclusively for pasturage and hay production-most of the hay land being given over to the growth of wild hay which is watered by the natural overflow of streams.

4. The work on these ranches is done under conditions which make it impracticable for the workers to have homes, and a great class of homeless, migratory farm laborers has been called into existence.

5. The circumstances of the life and labor of these migratory, homeless workers effectively prevent them from realizing a reasonable degree of human welfare, and the presence of such large numbers of men suffering from the evils to which they are exposed is a social menace. These evils are matters of common observation, and the statistics of crime, pauperism, and insanity furnish evidence as to their extent.

6. The existence of these great holdings of irrigated land effectively prevents the growth of a farm population to which the natural resources of the state entitle it and which is needed to give economic and social stability.

What to do is the question now. It is a useless and ungracious task to point out the economic and social ills of a state unless one looks forward to some procedure aimed at their eradication or diminution. What, then, can be done to improve the conditions of farm labor in Nevada so that such labor will contribute, not to the degradation of the worker, but to the development of a worthy citizenship? The answer is easily found: The great holdings of irrigated land must be cut up into small farms, farms of such size that most of the work will be done by the farmers and the members of their families. This would result in a tenfold increase in the 
number of farm homes, and the circumstances that produce homeless, migratory farm workers would no longer exist.

It is quite generally conceded that Nevada needs a larger population and that it has resources sufficient to support a much larger number of people than are now living within its borders. There has been some effort directed to the securing of such population, but it has been, in the main, futile. The problem is to find a practicable working device-a plan that will accomplish the purpose with due regard to all interests. Any plan of public control of range lands must conserve two interests, the just interests of the present range users, including all rights established by custom, and the interests of the future small farmers, whose interests are practically identical with those of the state and of society generally. The customary rights acquired by the stockmen during a halfcentury of national neglect should not be disregarded, neither should these rights be held to extend to what would amount practically to an ownership of the public land. The rights of stockmen should be recognized in the sense that the owners should be compensated for them, but this recognition should not extend to the point of permitting such vested rights to fasten a bad industrial system upon the state for all time to come. The following plan is offered for consideration. Only the broad outlines are given, since the details would depend upon a more complete investigation than has been made.

I. Let the government retain the ownership of all public lands which are more valuable for range pastures than for other purposes. The government should secure gradually by purchase certain tracts of land which have water necessary for the use of animals using range pastures.

2. All such public range lands should be placed under legal control, and the management should be intrusted to a public-lands commission under the Department of Agriculture or the Department of the Interior.

3. The system of management should be sufficiently elastic to permit of adaptation to various types of local conditions, but the general aim should be to encourage the multiplication of small farms and small live-stock owners and range users. To this end some such devices as the following could be used: 
a) The state should be divided into districts of such size and with such boundaries as to facilitate an economic use of the range pastures.

b) There should be established a system of control designed to conserve and increase the value of the pastures.

c) Provision should be made for the organization of co-operative live-stock associations, one association for each district-such associations to be open to all owners of cultivated land in the district and to include all users of public range land. These associations should co-operate in the management of live stock on the range, and the management should be such that a farmer with 40 acres and a few cattle and sheep would find it practicable to pasture his stock upon the public range.

d) All members of such associations should pay a rental for the use of the public range lands in the form of fees for pasturage. These fees should be more than merely nominal and should be less than the full rental value of the land.

e) Part of the income derived from such fees should be devoted to the administration and improvement of the range lands and to the purchase of lands on which drinking-water is found. The remainder should be turned over to the state to be used for the construction and maintenance of roads and for the maintenance of schools and other educational agencies.

f) The number of animals pastured for any one owner should bear some relation to the amount of land owned and under cultivation, but there should be a certain degree of discrimination in favor of the small farmer. Within certain limits the small farmer should be permitted to pasture as many cattle as he could grow winter feed for and a proportionate number of sheep. As the small farmers would avail themselves of this privilege, it would necessitate some reduction in the number of animals pastured by the big stockmen. This would result in a subdivision of the great holdings of irrigated land and the creation of numerous small farms. ${ }^{\text {. }}$

I The general policy of range management of the forest reserves is somewhat favorable to the use of the range by small farmers, and, where the previous system of land ownership was right, forest reserves are being used in about the way all the public range lands should be used. The Manti Forest Reserve in Utah, where more than two thousand small farmers pasture their cattle and sheep, is an excellent example of a wise use of the range pastures-a use which tends to create sound social conditions. 
A reduction in the number of animals pastured on the public range by the large landowners would diminish the value of the watered land to such owners. The collection of a pasturage fee would have a similar effect. This, of course, would tend to decrease the selling price of such privately owned land. On the other hand, the creation of a system of legal control with conservation methods would more than double the actual value of the public range pastures, and this would tend to increase the value of the adjacent privately owned land. By a proper adjustment of the rental fees it would be possible to make one tendency counterbalance the other and thus to maintain land values at about the existing point.

But during a period of years, while stable land values could be maintained at, or a little above, their present point, three important developments would result from an application of the plan I have proposed:

I. The value of land due to its proximity to public range lands would attach to the small farm as well as to the large, since the use of the range would be even more advantageously open to the small farmer.

2. The special value of a small tract of watered land to a large landholder, so far as such value arises out of the danger of unregulated competition and annoyance from a new owner, would disappear. The big landholder could sell 80 acres without endangering his whole system. He would decrease the amount of his land and his live stock somewhat, but he would not endanger the whole enterprise, for control would now be exercised by administrative procedure, not by a water monopoly.

3. As a result of the two developments mentioned above, the ordinary rule would apply, and the irrigated and irrigable land would have a greater value for the more intensive and diversified cultivation of the small farmer than for the less intensive use of the large farmer. As a consequence, the large landowners would be able to dispose of their lands gradually and at a price that would be advantageous. In this way would the great ranch with its migratory laborers be transformed into a large number of small 
farms, and the state would secure a higher degree of economic and political stability and of social welfare. ${ }^{\text {r }}$

The plan here set forth is sure to meet with certain objections, and it will be well to consider then in detail. In the first place, any effort to reverse a tendency which has characterized nearly the whole history of the state will raise suspicion among conservative men familiar with the situation. They will hold that the present situation is the normal outcome of an effort to utilize the natural resources of a region with the special climatic conditions prevailing in Nevada. It will be contended that the practical stockmen of Nevada have worked out a system which is best adapted to this state. From this point of view it would be reasonable to ask the national government for legislation of a character to aid development along existing lines, but not otherwise. ${ }^{2}$

The second objection is directly opposed to the first and will be made by men familiar with certain economic doctrines, but not with the practical situation. It will be held that any effort to

The practical outcome may appear more clearly from an illustrative case. There is a certain tract of irrigated land 8 miles long and $2 \frac{1}{2}$ miles wide. This land is all owned by a corporation, and the stock of the corporation is practically all owned by two men. This corporation also owns all the watered land over the adjacent mountainous region, and thus it secures a monopoly of pasturage sufficient to maintain 20,000 head of cattle. The irrigated land furnishes sufficient wild hay for winter use. This great area supports a very few families and a large number of migratory farm workers varying according to the season. Under the plan above proposed the irrigable land, which is adapted to diversified farming, could be divided into two or three hundred farms, and if the two or three hundred small owners were to have the use of the adjacent public range lands, they would be able to secure an annual income sufficient to maintain themselves according to a reasonable American standard of living. A farm population of such size would support a village of sufficient size to serve as a social center for the whole community. There could be a church or two, a good school, and reasonable opportunities for beneficial sorts of recreation and amusement. In short, this great ranch which is now conducted in such a way as to contribute to the degradation of some hundreds of homeless migratory workers could be made to support in comfort, and under favorable moral conditions, a home population of 1,500 people. There are scores of ranches of essentially similar possibilities.

${ }^{2}$ The Pittman Land Grant bill which passed the United States Senate February 8, I9I6, may be considered a practical effort in harmony with this viewpoint, since its practical effect would be a further development of water monopoly and large-scale live-stock production. Such a development would cut off the state's best opportunity for securing a population of a character to give it economic and social stability. 
bring about a subdivision of the great land holdings is needless, because such subdivision is sure to come about at no distant date as a result of the working of natural economic laws. It is very generally true that the big farm is a mere incident of pioneer conditions. Witness the gradual subdivision of the great farms of California, Texas, and the Dakotas. There are, however, some exceptions to this general rule, and the lands of Nevada constitute an exception.

Then there will be the objections arising out of the special interests of present landowners. Although governmental action designed to bring about a subdivision of the large ranches should be of such a character as to conserve the rights of the present owners or to recompense them fairly for such rights, it is pretty certain that some owners would be alarmed in the beginning and would feel it necessary to contend for the maintenance of existing conditions in order to maintain their rights. And finally there is good reason to believe that the men who dominate the use of the public range lands are not satisfied with the rights now theirs, but that they desire to increase and strengthen such rights. ${ }^{x}$ A policy designed to compensate them for existing rights, but not for rights hoped for, might meet as much opposition as if it were to deprive them of rights already owned.

For convenience I will restate these four objections more briefly and then consider each in turn.

Objection I.-The present system of large land holdings is the normal outcome of an effort to make an economic use of the land under the special topographic and climatic conditions prevailing in Nevada.

I The rights of the present landowners to the use of the public range lands are subject to some pretty serious limitations. In the first place, their rights are merely customary not legal, rights. The stockmen are permitted trespassers on the public land. They cannot enforce their rights by legal procedure. In the second place, there is no assurance that the status of permitted trespassers will be a permanent one. The possibility and even probability that the national government will assume control of the public grazing lands is ever present. And finally, the customary rights at present enjoyed are not sufficient to permit of an economic use of the range. There is abundant reason for believing that the present landowners would welcome legislation of a character to give them a legal status as users of the public range and to increase the economic value of the range lands, provided such legislation were to leave them in full possession of the benefits accruing therefrom. 
This objection is met by the statement that the system of large ownership is not the result of physical conditions merely, but of physical conditions plus certain legal conditions. If the legal conditions had been right, there would have been a system of land ownership characterized by the existence of numerous small farms, and under such a system the farm lands and the range lands would have been utilized more advantageously. What was needed was a system of control of public range land which would secure for the small farmer a peaceful use of the public range by administrative procedure. The big stockmen bought more than two million acres of land mainly in order to secure control of public range land which the owner (the public) should have controlled. Had the government controlled this land appropriately, most of the privately owned range land would have had small value to the owners, since its ownership would not have given a control over adjacent public land.

This point may be made a little clearer by reference to the situation in a certain valley and its adjacent mountain ranges. There were several farms, each with an individual owner. Each farmer owned irrigable land and water for irrigation. Some of the water was used for irrigation, and there was a prospect for a gradual extension of the irrigated area. Furthermore, each farmer had sheep or cattle or both pasturing on the adjacent public lands in the mountains. To these pastures no one had any legal right and each tried to get all he could. A typical case of trouble might arise as follows: Mr. A. had pastured his sheep on a certain range for a few years and had come to regard it as his own by custom and to depend on it. Some new landless sheepman drove his sheep over Mr. A's. range, taking much of the pasturage. This forced Mr. A. to drive his sheep into a new section, perhaps into Mr. B.'s cattle range. This made the range practically worthless for cattle, and Mr. B. was up in arms. He wanted revenge on Mr. A. and probably got it, but he was in urgent need of pastures for his cattle, and so he invaded the preserves of Mr. C., thus extending the area of private warfare. Such a war among stockmen was exceedingly expensive in the lives of sheep and cattle and sometimes in the lives of men. Now these stockmen began to buy up the land which 
had water sufficient for drinking purposes. In this way they were able to protect their customary ranges to some extent. But this process took place gradually, and the land purchased by each was scattered around not very systematically, so that no one of them owned an exclusive control of his range, and the trouble continued. In the course of time Mr. A., a man of considerable enterprise, succeeded in getting enough land here and there all over the district to annoy his neighbors very greatly. He then began to buy out the other landowners, one by one, and finally secured a complete monopoly of the water supply and more or less perfect control of the pasturage of the whole region. This control was further perfected by the growth of understandings between $\mathrm{Mr}$. A. and other big stockmen who had secured similar control of the pastures of adjacent districts. Legislation designed to discourage the landless sheepman served to reduce the competition still further. After this there was comparatively little trouble in the use of the range, and the business became more profitable. This control is not, however, sufficiently perfect to encourage the use of adequate methods of range management designed to conserve the pasturage.

Now two things are to be noted here. The consolidation of several ranches into one was economic; it made the business more profitable. In this sense the consolidation represents a natural economic development. But this advantage was not the result of superior cultivation or better management, using that word in its ordinary sense. The balance of advantage lay solely in the fact that peace was secured. Had the national government managed the public lands in such a way as to make it possible for the small farmers to utilize the public range lands peaceably the great land holdings would not have come into existence. The lack of such policy is the cause of the growth of the great corporate land holdings. When the government establishes an appropriate system of rangeland management these great holdings will be subdivided.

Objection 2.-There is no need of any effort to bring about a subdivsion of the large land holdings, because they are sure to be subdivided in the near future as a result of the working of natural economic laws. 
The privately owned land of the big ranges derives its value from two different sources: (I) it is valuable for the production of crops, and (2) it is valuable for the control of the adjacent range lands. It is important to keep this distinction clearly in mind. Here is a quarter-section of watered land, a part of a great ranch, worth to its owner-a big stockman- $\$ 5^{\circ}$ an acre for purposes of hay production. It would be worth $\$$ roo an acre for more intensive use by a small farmer. Under these circumstances we should expect ordinarily that the land would be sold so that it could be applied to the production of those crops for which it is most valuable. But such is not the case. The big stockman cannot afford to sell this quarter-section because it would break his system of control over the district. A new owner might contend for the use of ten or twenty thousand acres of public land and he would be in a position to get it or to make unlimited trouble, since he would own a supply of water. ${ }^{\text {. }}$ The big stockman could not afford to sell this land for twice what it would be worth to a small farmer. Why not, then, sell the entire ranch after subdividing it into small farms of appropriate size? For this reason: So long as all of the land is in a single ownership it has the value arising from its monopoly control over the adjacent public range lands. If it is subdivided, it loses this value. The buyers of a hundred small farms could afford to pay only what the land would be worth for production and possibly for the privilege of entering into a scramble for the use of some part of the range-a privilege of little or no

The ability of a small landowner to annoy the big stockman has, in some places, resulted in a curious sort of enterprise which the big stockmen consider somewhat in the nature of blackmail. Some man goes out into the mountains and finds some public land with a little water on it-enough for drinking purposes and possibly enough to irrigate a garden or a few acres of hay land. He homesteads the land, builds some sort of a shelter, and establishes a home. He makes his living in two ways-by stealing cattle and sheep and by the collection of trespass damages when the live stock of the big proprietor gets on his homestead. After annoying the stockman in these ways for a time, he may be able to sell his little "farm" to the stockman for a price measured, not by its value for production, but by its importance as a nuisance. A different situation is presented in the case of a man who, lacking in business sagacity and aggressiveness and influenced by the rosy prospects held out by land advertisements, buys a little land, believing that he will be able to make a farm out of it. Lacking the means of self-defense, he may be driven out with little or no compensation by a ruthless stockman who wants the water for his stock. 
value to a man of moderate means. But this value for production would be much less than the value for range control. Consequently, if the owner of a great range containing several thousand acres of irrigated land were to subdivide and sell the land for what he could get, he would suffer serious loss. In view of these facts we are not justified in expecting a subdivision of the great land holdings so long as the present legal situation exists. So long as a peaceful use of the range pastures can be secured only through water monopoly, this system will continue. There is no present tendency toward a subdivision of the large stock ranches. In fact, there is evidence of further consolidation of ownership. In 1900 the large ranches had 66.7 per cent of the total area of improved land in the state and in I9ro they had 70.2 per cent. And this is true in face of the fact that, in one county, a subdivision of a few large ranches came about through the operation of the reclamation act.

By way of exception there are a few valleys in the state where the conditions are such that the ownership of watered land does not confer control over public range pastures. In these valleys much of the land is found in farms of small or moderate size, and there is a tendency toward a subdivision of the larger holdings. These exceptions tend to prove that the ordinary rule as to the subdivision of large land holdings would apply in Nevada were it not for the relation of water monoply to range control.

Objection 3.-A policy designed to work in the interest of a subdivision of the large ranches would endanger the just rights of the present owners.

This objection should be met by a plan that would enable the present landowners to sell their holdings at a fair price, so that they would not suffer injustice. They should not be held as blameworthy for the present system. They have done as well as could be expected under the circumstances. The responsibility rests upon the negligent landlord-the national government-and any effort to remedy the situation should be based on a recognition of the customary range rights enjoyed by the present range users. A wise system of management of public range land would make it possible for the owners of great tracts of irrigated land to sell such land advantageously. 
Objection 4. $-A$ policy designed to secure a subdivision of the great ranches would arouse the opposition of the present owners because it would preclude the acquisition of further valuable rights by such awners.

The ambition of the great landowners to control vast areas should not take precedence over the demand for a higher state of welfare for the workers nor over the public interest. The future increments of range value which will arise as a result of a system of control of public range and through conservation methods thereby made possible should not be given to the present range users, but should be devoted to financing sound social conditions, and this policy should be insisted on most firmly despite all objections.

The management of the public range lands of the United States presents problems worthy of serious and statesmanlike consideration. The problems relate to the conservation and development of the pastures of these great areas and to their economic utilization. But even more important is the problem of creating right labor conditions and conditions of social soundness. In closing, I wish to make a plea for a careful study of the whole situation - a more complete study than has been made, a study of the social, as well as of the purely economic, aspects of the question. Such a study might be made under the authority of Congress or through the instrumentality of one of the great private foundations for research. Until such a study is made, the national government should retain the ownership of all public lands more valuable for pasturage than for cultivation. 